\title{
Effects of Cissus Populnea on the Rheological Properties of Local Clay
}

\author{
Adeoluwa O. Oluwaseyi, Charles C. Omohimoria and Adetokunbo A. Falade \\ Department of Mineral and Petroleum Resources Engineering Technology, Federal Polytechnic, Ado-Ekiti, Nigeria \\ oluwaseyi_ao@fedpolyado.edu.ng | omohimoriacharles@gmail.com I ademola201052@yahoo.com
}

Received: 11-FEB-2021; Reviewed: 12-MAR-2021; Accepted: 07-MAY-2021

http://dx.doi.org/10.46792/fuoyejet.v6i2.616

\begin{abstract}
Globally, Wyoming bentonite has been observed as the only accepted drilling fluid. Hence, the importance of investigating the mode by which Cissus populnea affects the rheological properties of local clay and as possible substitute for the international standard clay as drilling fluid. Ten samples of the local mud were taken at different locations of Afuze deposit, the stem bark of Cissus populnea was purchased in Ekiti State and authenticated at the herbarium, University of Ibadan, Nigeria. Its extraction was effected using the soxhlet extractor apparatus. Samples A and C, were respectively the mud of the local clay and a mixture of the Cissus populnea extract and the local clay. A control sample, B was formed from a mixture of water and the International Standard Wyoming bentonite which was obtained from the Petroleum Engineering Department of the University of Ibadan. Rheological properties of each of the samples were determined. The results of sample $\mathrm{C}$ (density (9.85 lb/gal), $\mathrm{pH}(9.9-11.3)$; funnel viscosity (50-62 seconds); hydroxylethyl cellulose at $600 \mathrm{rpm}(22-38 \mathrm{cp})$; filtrate value $(13.0-15.8 \mathrm{ml})$; sand content $(0.50-0.81 \mathrm{ppg})$; gel strength $\left(15-21 \mathrm{lb} / 100 \mathrm{ft}^{2}\right)$ and yield stress $\left.\left(7-13 \mathrm{lb} / 100 \mathrm{ft}^{2}\right)\right)$ fell within the API $\mathrm{RP}-13 \mathrm{~B}$ standard for drilling fluid. The analysis showed that the differences between samples $\mathrm{A}, \mathrm{B}$ and $\mathrm{C}$ were negligible and that the local clay treated with Cissus populnea can serve as a substitute for foreign clay.
\end{abstract}

Keywords- bentonite, Cissus Populnea, local clay, mud weight, rheological properties

\section{INTRODUCTION}

There is a global observed convention of the Wyoming bentonite as the only accepted drilling fluid material for drilling oil and gas rocks. Over the years the conventional rheological properties which have been examined are: Viscosity, gel strength, sand content, mud density, $\mathrm{pH}$ and lubricity. Wyoming clay has a specified value that is conventionally accepted as the American Petroleum Institute Standard (API) for drilling mud (Ogbeide, 2016). Originally, drilling fluids was designed to remove cuttings pieces of rock continuously, but development in drilling sector demanded more sophisticated form of drilling mud. Several types of additives, which were the sophisticated mixture of liquids, were introduced so as to enhance the usage of drilling fluids (Onojak and Chikwe, 2019; Omohimoria and Falade, 2017; Growcock and Harvey, 2005; Muds, 2000). A circulating system on any drilling rig is a closed loop of activities consisting primarily of a drilling fluid which is the workhorse of the whole drilling operation and other equipment which aid in the circulation of the drilling fluid (Skalle, 2011).

The drilling fluid consists of a combination of natural and synthetic compounds used for a variety of purposes. API defined it as a circulating fluid used in rotary drilling to carry out any or all of the various tasks required in drilling operations. A good drilling fluid has to be generally simple with a number of additives such as barite which is added to the fluid to control its density and is of commercially quantity in Nigeria (Kolawole et al., 2019). Most often, due to lack of basic understanding, foreign mud systems end up disappointing the local customers (Fink, 2011).

*Corresponding Author

Section D- MATERIALS ENGINEERING \& RELATED CHEMICAL SCIENCES Can be cited as:

Oluwaseyi A.O., Omohimoria C.C. and Falade A.A. (2021): Effects of Cissus Populnea on the Rheological Properties of Local Clay, FUOYE Journal of Engineering and Technology (FUOYEJET), 6(2), 83-87. http://dx.doi.org/10.46792/fuoyejet.v6i2.616
Different challenges encountered during drilling operations have led to formulation of different types of drilling fluid. Water Base Mud (WBM) is largely used in the industry due to its environmentally tolerable and relatively cheap nature. Dispersed Mud, as a type of WBM is basically used at greater depths requiring higher densities or in problematic conditions of drill-hole where heightened treatments are required. The mud system would be dispersed with specific additives to give specific properties which can be thinners or dispersants. On the other hand, non - dispersed mud is employed in shallow wells or top-hole sections. Its water is allowed to react with formations containing shales/clays so that the mud will form solids content and density naturally. Salt water mud could either be a saturated salt system with chlorides concentration around 190,000 mg/l, which is suitable for salt formation drilling in order to prevent dissolving, or a saltwater system where chloride concentration lies between 10,000 and 190,000 mg/l (Van Dyke and Baker, 1998; Hawker, 2001).

Another major drilling fluid is the Oil Base Mud (OBM) which has oil as their continuous phase, diesel oil, mineral oil or low toxicity mineral oil, with no additional water or brine, even though, they may pick up water from the formation. Invert Emulsion Mud as a type of OBM are water-in-oil emulsions typically with base oil or diesel as the continuous phase with up to $50 \%$ brine in the emulsifier phase. They find more application in stable, water sensitive formations and in inclined bore holes. They are of high thermal stabilities and provide excellent corrosion protection. The high price, great risk if gases reservoirs are bored through with their huge environmental problems are some of its demerits. In Emulsion mud water is the major continuous phase, with oil making up the dispersed phase, normally between 5$10 \%$. Environmental issues and cost are both reduced; there is improved lubricity, reduced torque and drag effects, increased rate of penetration and reduced filter loss. 


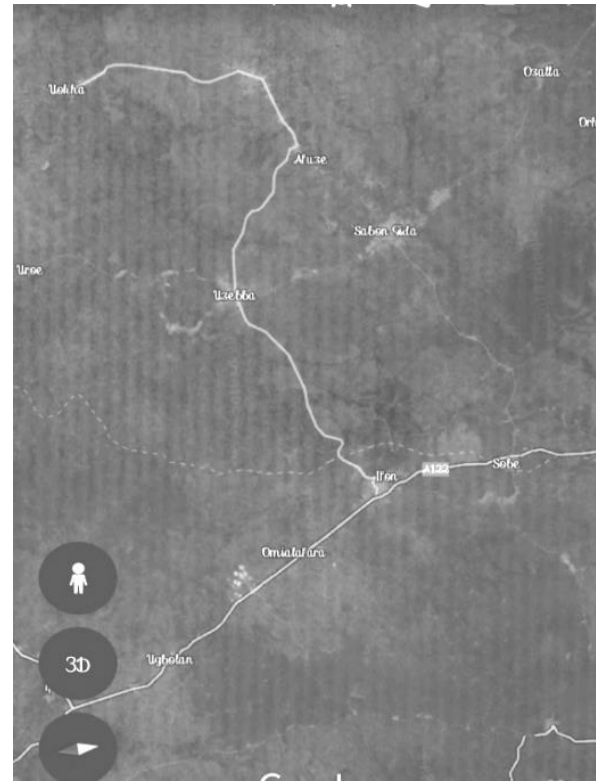

Fig. 1: Location map of Afuze,

(Source: Falobi and Silas-lyoho, 2018)

Also, Synthetic-Base Mud (SBM) was born out of an increased desire to reduce the environment impact of offshore drilling operations. The Synthetic-Base Mud was developed by duly considering its cost effectiveness. SBM can be applied to minimize wellbore stability problems arising from reactive shales, maximize the rate of penetration and increase lubricity in directional and horizontal wells: Esters, ethers and poly or isomerized alpha olefins are some of its examples (Fink, 2011). The choice of a drilling fluid will depend on the cost of production, technical capabilities and environmental effects. Most important of all the three, is the technical performance of the drilling mud (Hawker, 2001).

Cissus populnea is a plant associated with a myriad of medicinal uses in different parts of the world. Its products have been attributed to the antibacterial properties (Koné et al., 2004; Atawodi et al., 2002; Moody et al., 2003). In Yoruba land, South West Nigeria, its uses are linked with aphrodisiac/fertility abilities (Ojekale et al., 2006) and for the purpose of pharmaceutical uses, Adeleye et al. (2015) carried out detailed study on its physicochemical and rheological properties. However, the rheological properties modified with Cissus populnea have not been explored enough in the extractive industries.

Nigeria being one of the major producers of crude oil in the World and the availability of clay which is found in commercial quantity in several parts of the nation formed the basis for studying the effects of Cissus populnea on the rheological properties of locally sourced clay.

\section{Materials AND Methods}

The stem bark of Cissus populnea was purchased and authenticated at the herbarium of the University of Ibadan, Nigeria. The extraction was carried out as early as possible using the soxhlet extractor apparatus where the stem bark was kept inside a solvent; a mixture of acetone and chloroform. During the extraction, the heating mantle was switched on and after all the extraction was made from the stem bark at $122^{\circ} \mathrm{F}\left(50^{\circ} \mathrm{C}\right)$ for 30 minutes, the fluid of the stem bark was mixed up with the solvent which was later poured into a container and decanted such that the extract was obtained as it's not miscible with the solvent.

Locally sourced clay was obtained from Afuze (shown in Fig. 1) in Edo state, Nigeria. Ten samples were taken from different locations of the pit where Artisan Clay Miners were extracting clay for local use. All the tests for the rheological properties were carried out at the Petroleum Engineering Laboratory, University of Ibadan, Nigeria, according to the standard of American Petroleum Institute (API RP-13B). Its physico-chemical properties have been carried out by some authors and according to Ihekweme et al. (2020) the clay showed sheets of kaolinite and quartz flakes.

\subsection{Procedure for the Preparation of the Locally SOURCEd CLAY MUd}

About $25 \mathrm{~g}$ of prepared fine Afuze clay was added to 350 $\mathrm{ml}$ of fresh water to give mud of specified densities in ppg and was stirred with the multi-beach mixer for 30 minutes. After 25 minutes of stirring, the lumped material adhering to the spindle of the container was scraped down. The $\mathrm{pH}$ was adjusted to $9.5 \pm 0.1$ with either phosphoric acid or a caustic solution as required. The stirring was resumed for a specified period. At the end of the stirring time, the sample was moved into a sealed jar and aged for $24 \mathrm{hrs}$ at room temperature. This served as sample A.

\subsection{Procedure for the Preparation of Wyoming BENTONITE MUD}

The same procedure used in 2.1 was employed in preparing Wyoming bentonite mud and was labelled as sample B that served as control sample.

Table 1. API Standard Test Values for Drilling Mud (Akinwumi, 2015)

\begin{tabular}{cc}
\hline Drilling Fluid Property & Value Requirement \\
\hline Mud density (lb/gal) & $8.65-9.60$ \\
Viscometer dial reading & $30 \mathrm{cP}$ \\
@600rpm & $8-10$ \\
Plastic viscosity (cP) & $3 \times$ plastic viscosity \\
Yield point (Ib/100ft2) & $15.0 \mathrm{ml}$ maximum \\
Fluid loss (Water) & $9.5 \mathrm{~min}-12.5 \mathrm{max}$ \\
pH level & $(1-2) \%$ maximum \\
Sand content & $52-56$ sec/q+ \\
Marsh funnel viscosity & 91 (maximum) \\
Mud yield (bbi/ton) & 30 (minimum) \\
API filtrate (ml) & 26 sec/q+ \pm 0 \\
Marsh funnel viscosity for & water
\end{tabular}




\subsection{Procedure for the Preparation of Cissus Populnea Extract Plus local Clay Mud}

$83.3 \mathrm{ppg}$ of the prepared mud of sample A was added to $24.9 \mathrm{ppg}$ of aqueous extract, Cissus populnea. The mixture was aged for about seven days, and then homogenized in a Hamilton beach mixer. This was labelled Sample C.

\subsection{Procedure for the Determination of the DENSITY OF THE MUD}

The mixture of $350 \mathrm{ml}$ of water, $10 \mathrm{~g}$ of barite, $4 \mathrm{~g}$ of Sodium carbonate $\left(\mathrm{Na}_{2} \mathrm{CO}_{3}\right)$ and $1 \mathrm{~g}$ of Hydroxylethyl Cellulose was added to sample A, B and C. The density of each composition was determined according to the API RP-13B standard where the weight of a fixed volume of each of the freshly prepared mud samples was measured by moving a rider counterweight along a graduated scale. At the left-hand edge of the rider the density of the mud was read and recorded in pounds per gallon (ppg). Then, the sensitivity test was conducted for the following mixtures:

- $350 \mathrm{ml}$ of water, $15 \mathrm{~g}$ of barite, $5 \mathrm{~g}$ Sodium Carbonate and $1.5 \mathrm{~g}$ Hydroxylethyl cellulose

- $350 \mathrm{ml}$ of water, $20 \mathrm{~g}$ of barite, $6 \mathrm{~g}$ Sodium Carbonate and $2.0 \mathrm{~g}$ Hydroxylethyl cellulose

- $350 \mathrm{ml}$ of water, $25 \mathrm{~g}$ of barite, $7 \mathrm{~g}$ Sodium Carbonate and $2.5 \mathrm{~g}$ Hydroxylethyl cellulose

\subsection{Mud Viscosity Measurement}

Funnel was placed vertical and its orifice was covered with a thumb. Freshly prepared mud sample was poured through a screen into the clean and dried out funnel till its level reaches at least 1 quart under the funnel orifice. The finger was simultaneously removed from the orifice along with the starting of the Stop Watch. The time for the collection of 1 quart $(964 \mathrm{ml})$ of the mud sample into the cup was measure and recorded in seconds. This is the value of the funnel viscosity. The test was carried out for each of the three prepared mud samples.

\subsection{Procedure for the Viscometer Readings at 600 RPM AND 300 RPM}

A fixed volume of each of the mud samples A, B and C were poured separately inside the Baroid viscometer's cup and stirred thoroughly at 600 revolutions per minute (rpm) for about fifteen seconds. Then the gear was first slow lifted to the first and centre position that shut the motor off. After waited for $10 \mathrm{sec}$, the motor switch was quickly turned low at $300 \mathrm{rpm}$ and the initial reading was taken at the maximum deflection in unit of $\mathrm{cp}$. Immediately, the instrument was cleansed after a run and a fresh piece of paper was place on it to prevent screen sticking to the gasket. The sample was stirred again, at 600 rpm for ten seconds and was allowed to stand for ten minutes. Then, the maximum dial deflection at $300 \mathrm{rpm}$ was obtained and the values of the viscometer reading at 600 and $300 \mathrm{rpm}$ were observed and recorded.

\subsection{Gel Strength Determination}

API standard was used in this experiment. When the rotational viscometer was turned at low rotor speed, 3 $\mathrm{rpm}$, and in 10 minutes, the mud was stayed. Then, at the highest dials deflection the gel strength reading was taken and the result recorded.

\subsection{SAND Content Determination}

Separately, a Baroid glass tube was filled with a given amount of mud sample A, B and C. The mouth of the tube was closed with the thumb and shaken. The mixture was poured through the screen and the sand retained was washed to free it of any remaining mud. The screen was inverted slowly by turning the tip of the funnel mouth and washed the sand back into the graduated tube with a fine spray of water on the back side of the screen. The result of each mud sample A, B and C for the sand content that settled in the tube was measured in percentage and recorded.

\subsection{DETERMINATION OF HydROgEN ION CONCENTRATION}

About 1 in strip of the indicator paper was removed from the dispenser and was placed on the surface of each of the samples A, B and C until the paper was wet and the colour stabilized. Then the strip colour was matched and compared to that of the chart on the side of the dispenser. The reading of the mud's $\mathrm{pH}$ was recorded for sample A, $B$ and $C$.

\subsection{Filtrate Volume Test}

The test was separately carried out for samples A, B and $\mathrm{C}$ at room temperature and pressure of $700 \mathrm{kPa}$. The mud sample was poured into the cell of a model filter press and the lid secured. All the valves are placed in the correct position to allow for the application of pressure on the mud sample to be filtered. A sized and graduated cylinder was placed under the filtration tube. As the pressure was applied to sample test, the timing also began and the filtrate was collected into a graduated cylinder for 30 minutes. Then, the pressure on the test sample was relieved. The volume of the fluid collected was recorded as the fluid loss in millilitres (ml).

\section{Results And Discussions}

\subsection{DeNSITIES OF THE Mud SAMPLES}

The results gotten for the densities of the mud samples are shown in the Table 2. It was observed as the barite increased from $10 \mathrm{~g}$ to $25 \mathrm{~g}$, the densities of samples A, B and $C$ also increased from $8.05 \mathrm{ppg}$ to $10.4 \mathrm{ppg}$, $8.2 \mathrm{ppg}$ to $10.5 \mathrm{ppg}$ and 8.3 to $10.6 \mathrm{ppg}$ for samples A, B and C respectively. On the other hand, the difference in the densities of samples A, B and C is minimum. The mud densities for Sample A (9.2 ppg), B (9.3 ppg) and C (9.4 ppg) satisfied the API standard when $15 \mathrm{~g}$ of Barite was added to the fluid (Tables 1 and 2). In comparison, the locally sourced drilling mud and the imported mud densities were nearly the same.

Table 2. Densities of the Mud Samples A, B and C

\begin{tabular}{ccccc}
\hline S/N & Barite(g) & $\begin{array}{c}\text { Sample } \\
\text { A(ppg) }\end{array}$ & $\begin{array}{c}\text { Sample } \\
\text { B(ppg) }\end{array}$ & $\begin{array}{c}\text { Sample } \\
\text { C(ppg) }\end{array}$ \\
\hline 1 & 10 & 8.05 & 8.2 & 8.3 \\
2 & 15 & 9.2 & 9.3 & 9.4 \\
3 & 20 & 9.6 & 9.8 & 9.85 \\
4 & 25 & 10.4 & 10.5 & 10.6 \\
\hline
\end{tabular}




\subsection{PH OF MUD SAMPLES}

The results gotten for the $\mathrm{pH}$ of the mud samples are shown in the Table 3. Respectively, it was observed that the $\mathrm{pH}$ of the mud sample A increased from 8.2 to 11.2, sample B from 8.6 to 11.4 and sample C from 8.8 to 11.3. This result connotes that the difference between sample $B$ and $\mathrm{C}$ is insignificant. The addition of 5 to $6 \mathrm{~g}$ of $\mathrm{Na}_{2} \mathrm{CO}_{3}$ to sample $\mathrm{A}$ and $\mathrm{B}$ gave $\mathrm{pH}$ values that ranged from 9.7 to 11.4, and they fell within API standard (9.5 minimum and 12.5 maximum) while the value of $\mathrm{pH}$ for sample $\mathrm{A}$ (9.2) was below the required standard.

Table 3. $\mathrm{pH}$ of the Mud Samples

\begin{tabular}{|c|c|c|c|c|}
\hline $\mathbf{S} / \mathbf{N}$ & $\begin{array}{c}\mathrm{Na}_{2} \mathrm{CO}_{3} \\
(\mathrm{~g})\end{array}$ & $\begin{array}{c}\text { PH of } \\
\text { sample A }\end{array}$ & $\begin{array}{c}\text { PH of } \\
\text { sample B }\end{array}$ & $\begin{array}{c}\text { PH of } \\
\text { sample C }\end{array}$ \\
\hline 1 & 4 & 8.2 & 8.6 & 8.8 \\
\hline 2 & 5 & 9.2 & 9.7 & 9.9 \\
\hline 3 & 6 & 10.2 & 10.8 & 11.1 \\
\hline 4 & 7 & 11.2 & 11.4 & 11.3 \\
\hline
\end{tabular}

\subsection{FUNNEL VISCOSITY OF THE MUd SAMPLES}

Table 4 shows the funnel viscosity results obtained from increasing mass of hydroxylethyl cellulose. $1.0 \mathrm{~g}, 1.5 \mathrm{~g}, 1.6$ $\mathrm{g}$ and $1.7 \mathrm{~g}$ of ethyl cellulose that were added to the fluid mud samples caused the increase in funnel viscosity of sample A, from 35 to 61 seconds, sample B from 36 to 62 seconds and sample $C$ from 36 to 62 seconds. As observed, the funnel viscosity of sample $B$ and $C$ was the same from the analysis. If the amount of hydroxylethyl cellulose added to the fluid could be increased a bit beyond $1.6 \mathrm{~g}$, the acceptable API standard value of Funnel viscosity (52 to $56 \mathrm{sec} / \mathrm{q}^{+}$) can be achieved.

Table 4. Funnel Viscosity of the Mud Samples

\begin{tabular}{ccccc}
\hline S/N & $\begin{array}{c}\text { Hydroxyethyl } \\
\text { Cellulose(g) }\end{array}$ & $\begin{array}{c}\text { Funnel } \\
\text { Viscosity } \\
\text { of sample } \\
\text { A(sec) }\end{array}$ & $\begin{array}{c}\text { Funnel } \\
\text { Viscosity } \\
\text { of sample } \\
\text { B(sec) }\end{array}$ & $\begin{array}{c}\text { Funnel } \\
\text { Viscosity } \\
\text { of sample } \\
\text { C(sec) }\end{array}$ \\
\hline 1 & 1.0 & 35 & 36 & 36 \\
2 & 1.5 & 41 & 42 & 42 \\
3 & 1.6 & 49 & 50 & 50 \\
4 & 1.7 & 61 & 62 & 62 \\
\hline
\end{tabular}

\subsection{Filtrate Volume of Mud Samples}

The results gotten for filtrate volume of the mud samples A, B and C are shown in the Table 5. The results were obtained by increasing, in separate experiment, the mass of hydroethyl cellulose from $1.0 \mathrm{~g}$ to $2.5 \mathrm{~g}$ in the mud samples. This caused the increase in filtrate volume of sample A, from 14.0 to $17.0 \mathrm{ml}$, sample B from 13.4 to 16.3 $\mathrm{ml}$ and $C$ from 13.0 to $15.8 \mathrm{ml}$. It was observed that the results of samples A, B and C fell within the range of API standard of $15.0 \mathrm{ml}$.
Table 5. Filtrate Volume of Mud Samples

\begin{tabular}{ccccc}
\hline S/N & $\begin{array}{c}\text { Mass of } \\
\text { Hydroxylethyl } \\
\text { cellulose(g) }\end{array}$ & $\begin{array}{c}\text { Filtrate } \\
\text { Volume } \\
\text { Sample } \\
\text { A(ml) }\end{array}$ & $\begin{array}{c}\text { Filtrate } \\
\text { Volume } \\
\text { Sample } \\
\text { B(ml) }\end{array}$ & $\begin{array}{c}\text { Filtrate } \\
\text { Volume } \\
\text { Sample } \\
\text { C(ml) }\end{array}$ \\
\hline 1 & 1.0 & 14.0 & 13.4 & 13.0 \\
2 & 1.5 & 15.0 & 14.4 & 14.0 \\
3 & 2.0 & 16.0 & 15.4 & 15.0 \\
4 & 2.5 & 17.0 & 16.3 & 15.8 \\
\hline
\end{tabular}

\subsection{Mud Samples With Hydroxylethyl Cellulose at 300 AND 600 RPM}

The results gotten for the dial reading at 300 and $600 \mathrm{rpm}$ of mud samples are shown in Tables 6 and 7 respectively. The increment of the quantity of hydroxylethyl from $1.0 \mathrm{~g}$ to $2.5 \mathrm{~g}$ in each of the samples at $300 \mathrm{rpm}$, the viscometer reading in the mud sample A increased from 18 to 42 , B from 17 to 43 and $C$ from 16 to 43 . On the other hand, with the same increment in the quantity of hydroxylethyl, at $600 \mathrm{rpm}$, the reading in mud sample A increased from 26 to 58 , B from 24 to 56 and $C$ from 22 to 52 . With the above value, the API standard value of viscometer reading at $600 \mathrm{rpm}(30 \mathrm{cp})$ can be achieved.

Table 6. Reading at $300 \mathrm{rpm}$ of Mud Samples

\begin{tabular}{|c|c|c|c|c|}
\hline $\mathrm{S} / \mathrm{N}$ & $\begin{array}{c}\text { Mass of } \\
\text { Hydroxyl } \\
\text { Cellulose }(\mathrm{g})\end{array}$ & $\begin{array}{c}300 \mathrm{rpm} \\
\text { Sample } \\
\text { A }\end{array}$ & $\begin{array}{c}300 \mathrm{rpm} \\
\text { Sample } \\
\text { B }\end{array}$ & $\begin{array}{c}300 \mathrm{rpm} \\
\text { Sample } \\
\text { C }\end{array}$ \\
\hline 1 & 1.0 & 18 & 17 & 16 \\
\hline 2 & 1.5 & 23 & 22 & 20 \\
\hline 3 & 2.0 & 33 & 33 & 32 \\
\hline 4 & 2.5 & 42 & 43 & 43 \\
\hline
\end{tabular}

Table 7. Reading at $600 \mathrm{rpm}$

\begin{tabular}{ccccc}
\hline S/N & $\begin{array}{c}\text { Mass of } \\
\text { Hydroxyl ethyl } \\
\text { Cellulose(g) }\end{array}$ & $\begin{array}{c}600 \mathrm{rpm} \\
\text { Sample } \\
\text { A }\end{array}$ & $\begin{array}{c}600 \mathrm{rpm} \\
\text { Sample } \\
\text { B }\end{array}$ & $\begin{array}{c}600 \mathrm{rpm} \\
\text { Sample } \\
\text { C }\end{array}$ \\
\hline 1 & 1.0 & 26 & 24 & 22 \\
2 & 1.5 & 34 & 32 & 38 \\
3 & 2.0 & 44 & 42 & 38 \\
4 & 2.5 & 58 & 56 & 52 \\
\hline
\end{tabular}

\subsection{SAND Contents OF THE SAMPLES}

The results gotten for the sand content of samples A, B, and $C$ are shown in the Table 8 . It is observed, as the barite increased from $10 \mathrm{~g}$ to $25 \mathrm{~g}$, the sand content of samples $\mathrm{A}, \mathrm{B}$ and $\mathrm{C}$ also increased from $0.55 \mathrm{ppg}$ to $0.84 \mathrm{ppg}, 0.42$ ppg to $0.73 \mathrm{ppg}$ and 0.50 to $0.81 \mathrm{ppg}$ for the mud samples respectively. In accordance to API standard for mud fluid, all the above results of sand content of samples A, B and $\mathrm{C}$ are within the acceptable range. 
Table 8. Sand Content Test

\begin{tabular}{ccccc}
\hline S/N & Barite (g) & $\begin{array}{c}\text { Sample } \\
\text { A(ppg) }\end{array}$ & $\begin{array}{c}\text { Sample } \\
\text { B(ppg) }\end{array}$ & $\begin{array}{c}\text { Sample } \\
\text { C(ppg) }\end{array}$ \\
\hline 1 & 10 & 0.55 & 0.42 & 0.50 \\
2 & 15 & 0.65 & 0.52 & 0.60 \\
3 & 20 & 0.74 & 0.62 & 0.70 \\
4 & 25 & 0.84 & 0.73 & 0.81 \\
\hline
\end{tabular}

Table 9. Gel Strength (lb/100ft²)

\begin{tabular}{cccccccc}
\hline $\begin{array}{c}\text { Bari } \\
\text { te }\end{array}$ & $\begin{array}{c}\text { Ethyl } \\
\text { cellulose }\end{array}$ & \multicolumn{2}{c}{ Sample A } & \multicolumn{2}{c}{ Sample B } & \multicolumn{2}{c}{$\begin{array}{c}\text { Sample } \\
\text { C }\end{array}$} \\
\hline & & 10 & 10 & 10 & 10 & 10 & 10 \\
& & secs & mins & secs & mins & secs & mins \\
\hline 10 & 1.0 & 2 & 3 & 5 & 9 & 8 & 15 \\
15 & 1.5 & 4 & 5 & 7 & 11 & 10 & 17 \\
20 & 2.0 & 5 & 6 & 9 & 13 & 13 & 19 \\
25 & 2.5 & 8 & 9 & 11 & 15 & 14 & 21 \\
\hline
\end{tabular}

Table 10. Yield Stress (lb/100ft $\left.{ }^{2}\right)$

\begin{tabular}{ccccc}
\hline \multirow{2}{*}{ Barite } & $\begin{array}{c}\text { Ethyl } \\
\text { cellulose }\end{array}$ & $\begin{array}{c}\text { Sample } \\
\text { A }\end{array}$ & $\begin{array}{c}\text { Sample } \\
\text { B }\end{array}$ & $\begin{array}{c}\text { Sample } \\
\text { C }\end{array}$ \\
\hline 10 & 1.0 & 1 & 4 & 7 \\
15 & 1.5 & 3 & 6 & 9 \\
20 & 2.0 & 5 & 8 & 11 \\
25 & 2.5 & 7 & 5 & 13 \\
\hline
\end{tabular}

The result shown in Table 9 and 10 revealed that as addition of barite and hydroxylethyl cellulose increased, values of gel strength and yield stress increased. Sample C which was enhanced with Cissus polpunea had higher values (gel strength $\left(15-21 \mathrm{lb} / 100 \mathrm{ft}^{2}\right)$; yield stress (7-13 $\left.\mathrm{lb} / 100 \mathrm{ft}^{2}\right)$ ) than that of samples A and B.

\section{Conclusion}

Generally, in the rheological properties analysis carried out above, it was observed that the difference in the density, sand content, filtrate volume and $\mathrm{pH}$ values of the local clay (Sample A), Wyoming bentonite (Sample B) and the Cissus populnea extract modified local clay (Sample C) at increasing concentration of hydroxylethyl cellulose, barite and sodium carbonate is negligible and the values obtained for parameters analysed for sample $\mathrm{C}$ ( density (9.85 lb/gal), pH (9.9-11.3); Funnel viscosity (5062 seconds); hydroxylethyl cellulose at $600 \mathrm{rpm}(22-38 \mathrm{cp})$; sand content $(0.50-0.81 \mathrm{ppg})$; gel strength $\left(15-21 \mathrm{lb} / 100 \mathrm{ft}^{2}\right)$ and yield stress $\left(7-13 \mathrm{lb} / 100 \mathrm{ft}^{2}\right)$ fell within the API RP-13B standard for drilling mud fluid. This demonstrates that the local clay treated with additive of Cissus populnea extract can serve as a substitute for foreign clay.

Therefore, it is recommended that Cissus populnea be employed in Oil and Gas industries in Nigeria, and that detailed investigation be carried out on the quantity of local clay that is available and the continuous source of the Extract supply. This will save our Nation of foreign exchange and provide employment for the growing youth population both in Mining and Oil industries.

\section{REFERENCES}

Adeleye, O. A., Femi-Oyewo, M. N., and Odeniyi, M. A. (2015), Physicochemical and rheological characterization of Cissus populnea gum extracted by different solvents, West African Journal of Pharmacy, vol. 26, No. 1, pp. 113-126.

Akinwumi, E. A. (2015), Beneficiation of Nigeria Local Clay to Meet API Standard Specification for Drilling Fluid Formulation. (A Case Study of Abbi Clay Deposit, Delta State), International Journal of Engineering Sciences \& Management, vol. 5, No. 3, pp 15 - 28.

Atawodi, S. E., Ameh, D. A., Ibrahim, S., Andrew, J. N., Nzelibe, H. C., Onyike, E. O., Anigo, K. M., Abu, E. A., James, D. B., Njoku, G. C., and Sallau, A. B. (2002), Indigenous knowledge system for treatment of trypanosomiasis in Kaduna State of Nigeria, Journal of Ethnopharmacology, vol. 79, No. 2, pp. 279-282.

Falobi, E. E., and Silas-Iyoho S. G. (2018), Effect of Cissus Populnea on the Rheological Properties of Local Clay Bentonite. Unpublished Undergraduate HND Project report, Mining Engineering Technology, The Federal Polytechnic, Ado-Ekiti, Nigeria.

Fink, J. K. (2011), Petroleum engineer's guide to oil field chemicals and fluids, Access Online via Elsevier. Retrieved on 20 $0^{\text {th }}$ March, 2021 from http:/doi.org/10.1016/C2009-061871-7

Growcock, F. and Harvey, T. (2005), Drilling Fluids Processing Handbook, In ASME Shale Committee, Elsevier. Retrieved December 13, 2020, from https://en.wikipedia.org/wiki/Herschel-Bulkley_Fluid.

Hawker, D. (2001), Drilling Fluid Hydraulics, Manual, (pp. 8-14), Stavanger: Datalog.

Ihekweme, G. O., Shondo, J. N., Orisekeh, K. I., Kalu-Uka, G. M., Nwuzor, I. C., and Onwualu, A. P. (2020). Characterization of certain Nigerian clay minerals for water purification and other industrial applications. Heliyon, vol. 6, pp. 1-11. Retrieved: 20 ${ }^{\text {th }}$ April, 2021 from https://doi.org/10.1016/j.heliyon.2020.e03783

Kolawole, F. O., Olugbemi, O. M., Madueke, C. I., and Kolawole, S. K. (2019), Comparison of Nigerian Barite Production with some Top Barite Producing Countries, FUOYE Journal of Engineering and Technology (FUOYEJET), vol. 4, No. 3, pp. 7-13.

Kone, W. M., Atindehou, K. K., Terreaux, C., Hostettmann, K., Traore, D., and Dosso, M. (2004), Traditional medicine in North Côte-d'Ivoire: screening of 50 medicinal plants for antibacterial activity. Journal of Ethnopharmacology, vol. 93, No. 1, pp.43-49.

Moody J. O., Ojo O. O., Omotade O. O., Adeyemo A. A., Olumese P. E. and Ogundipe O. O. (2003), Anti-sickling potential of a Nigerian Herbal Formula (Ajawaron HF) and the major Plant component (Cissus populnea L. CPK). US National Library of Medicine National Institutes of Health, vol. 17, No. 10, pp. 1173-6.

Muds, O. B. (2000). Stabilizing boreholes while drilling reactive shale formations with silicate-base drilling fluids. Drilling Contractor.

Ogbeide, P. O., and Igbinere, S. A. (2016), The Effect of Additives on Rheological Properties of Drilling Fluid in Highly Deviated Wells, FUTO Journal Series (FUTOJNLS), vol. 2 No. 2, pp. 68 - 82.

Ojekale, A. B., Lawal, O. A., Lasisi, A. K., and Adeleke, T. I. (2006), Phytochemisty and Spermatogenic Potentials of Aqueous Extract of Cissus populnea (Guill. and Per) Stem Bark, The Scientific World Journal, vol. 6, pp. 2140-2146.

Omohimoria C. and Falade A. (2017), Comparative Study of the Rheological Properties of Local Clay (Afuze) as a Possible Replacement for Imported Bentonite in Drilling Fluids Formulation, International Journal of Scientific \& Engineering Research, vol. 8 No. 11, pp. 249-255.

Onojake, M. C. and Chikwe, T. N., (2019), Rheological Properties of some oil based muds used in Reservoirs in the Niger Delta, Nigeria, Global Journal of Pure and Applied Sciences vol. 25, pp. 39-44

Skalle P., S. (2011). Drilling fluids engineering, Ventus publishing Aps Van Dyke, K., and Baker, R. (1998). Drilling Fluids, Mud Pumps, and Conditioning Equipment, University of Texas at Austin. 